\title{
DEVELOPMENT AND VALIDATION OF NEW STABILITY INDICATING REVERSED-PHASE HIGH-PERFORMANCE LIQUID CHROMATOGRAPHY METHOD FOR SIMULTANEOUS DETERMINATION OF METFORMIN HYDROCHLORIDE AND ERTUGLIFLOZIN IN BULK AND PHARMACEUTICAL DOSAGE FORM
}

\author{
VENKATESWARA RAO P ${ }^{1 *}$, LAKSHMANA RAO A ${ }^{2}$, PRASAD SVUM ${ }^{3}$ \\ ${ }^{1}$ Department of Pharmacy, JNTUK University, Kakinada, Vikas College of Pharmacy, Vissanapeta, Andhra Pradesh, India. ${ }^{2}$ Department of \\ Pharmacy, V. V. Institute of Pharmaceutical Sciences, Gudlavalleru, Andhra Pradesh, India. ${ }^{3}$ Department of Pharmacy, School of Pharmacy, \\ JNTUK University, Kakinada, Andhra Pradesh, India. Email: dralrao@gmail.com
}

Received: 06 August 2018, Revised and Accepted: 25 September 2018

ABSTRACT

Objective: The present study deals with the development, validation, and application of simple, precise, and accurate high-performance liquid chromatography (HPLC) method for the simultaneous estimation of metformin hydrochloride and ertugliflozin in pharmaceutical formulation and to validate.

Methods: The analytical conditions were optimized on BDS C8 column (150 $\mathrm{mm} \times 4.6 \mathrm{~mm}, 5 \mu \mathrm{m})$ at room temperature. The mobile phase consists of buffer: acetonitrile in 55:45 v/v ratio. Injection volume was $10 \mu \mathrm{l}$. The flow rate was maintained at $1.0 \mathrm{ml} / \mathrm{min}$, and the analysis was carried out at $224 \mathrm{~nm}$.

Results: The method was found to be linear in the concentration range of $125-750 \mu \mathrm{g} / \mathrm{ml}$ and $1.875-11.25 \mu \mathrm{g} / \mathrm{ml}$ for metformin hydrochloride and ertugliflozin with regression coefficient $r^{2}=0.999$. The method was found to be precise with percentage relative standard deviation below $2 \%$. The limit of detection and limit of quantification were found to be within the limits. The percentage recovery of the developed method was $100.15 \%$. All the validation parameters such as robustness, recovery, and precision were found to be within the limits. Degradation parameters such as acid, base, thermal and peroxide, light, temperature, and humidity were performed and found that the drugs are stable in all the extreme conditions.

Conclusions: A simple, accurate, precise, and less time-consuming reversed-phase HPLC method for the simultaneous estimation of metformin hydrochloride and ertugliflozin has been developed and validated in accordance with the ICH guidelines.

Keywords: Metformin hydrochloride, Ertugliflozin, Reversed-phase - high-performance liquid chromatography, Validation, Simultaneous, Degradation. (c) 2019 The Authors. Published by Innovare Academic Sciences Pvt Ltd. This is an open access article under the CC BY license (http://creativecommons. org/licenses/by/4. 0/) DOI: http://dx.doi.org/10.22159/ajpcr.2019.v12i1.28938

\section{INTRODUCTION}

Type 2 diabetes is a disease in which the body does not make enough insulin to control the level of glucose in the blood or when the body is unable to use insulin effectively. The result is a high level of glucose in the blood. The two active substances such as metformin hydrochloride and ertugliflozin work in different ways to lower glucose levels. Metformin hydrochloride is an antihyperglycemic agent (AHA) that improves glucose tolerance in patients with type 2 diabetes mellitus by lowering both basal and post-prandial plasma glucose. It is not chemically or pharmacologically related to any other class of oral AHA. Metformin decreases hepatic glucose production, decreases intestinal absorption of glucose, and improves insulin sensitivity by increasing peripheral glucose uptake, and utilization ertugliflozin helps to lower blood glucose by making the patient pass out glucose in the urine. It does this by blocking a protein in the kidneys (called sodium-glucose cotransporter-2 [SGLT2]) that normally take glucose back into the blood from the kidneys $[1,2]$.

Metformin hydrochloride is chemically called as N, N-dimethylimidodicarbonimidic diamide hydrochloride (Fig. 1) and does not related to any other classes of oral antihyperglycemic agents. It is a white to off-white crystalline compound with a molecular formula of $\mathrm{C}_{4} \mathrm{H}_{11} \mathrm{~N}_{5} \cdot \mathrm{HCl}[3]$

Ertugliflozin is the fourth SGLT2 inhibitor approved by the FDA. The chemical name of ertugliflozin L-pyroglutamic acid is $(1 S, 2 S, 3 S, 4 R, 5 S)$-5-(4- chloro-3-(4-ethoxy benzyl)phenyl)-1-(hydroxymethyl)-6,8-dioxabicyclo octane-2,3,4-triol, compound with (2S)-5oxopyrrolidine- 2-carboxylic acid (Fig. 2), and its molecular formula is $\mathrm{C}_{8} \mathrm{H}_{15} \mathrm{NO}_{2}[4,5]$

Even though numerous methods are available for the estimation of metformin hydrochloride individually and in combination with other drugs, no method has been reported for the estimation of metformin hydrochloride and ertugliflozin simultaneously [6-16]

\section{METHODS}

The reference sample of metformin hydrochloride and ertugliflozin was obtained as a gift samples, and the tablet containing metformin hydrochloride $500 \mathrm{mg}$ and ertugliflozin $7.5 \mathrm{mg}$ was procured from the local market. Water (high-performance liquid chromatography [HPLC] grade) from Rankem; acetonitrile (HPLC grade), orthophosphoric acid (AR grade), sodium hydroxide (pure), and hydrogen peroxide (pure) from Merck Ltd., and $0.45 \mu \mathrm{m}$ Nylon filter was from Zodiac life sciences were used.

\section{Instrumentation}

Waters HPLC 2695 system equipped with quaternary pumps, photodiode array detector, and autosampler integrated with Empower 2 Software. UV-VIS spectrophotometer, PG Instruments T60 with special bandwidth of $2 \mathrm{~mm}$ and $10 \mathrm{~mm}$, and matched quartz cells integrated with UV win 6 software were used for measuring absorbances of metformin hydrochloride and ertugliflozin solutions, Electronic Balance, Denver pH meter, Ultrasonicator - BVK Enterprises India. 


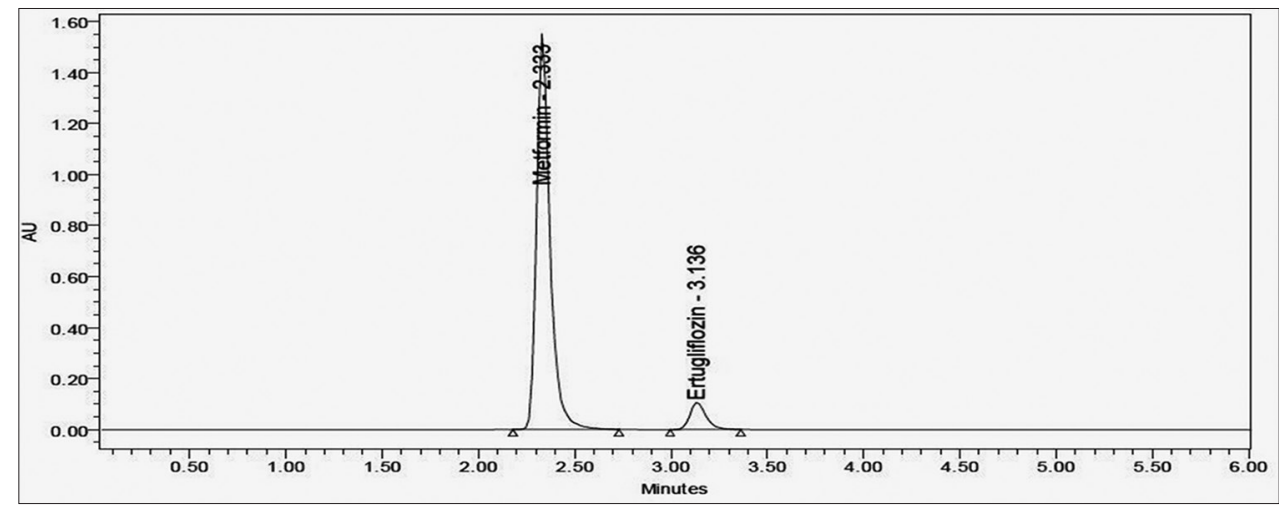

Fig. 1: Typical chromatogram of metformin hydrochloride and ertugliflozin

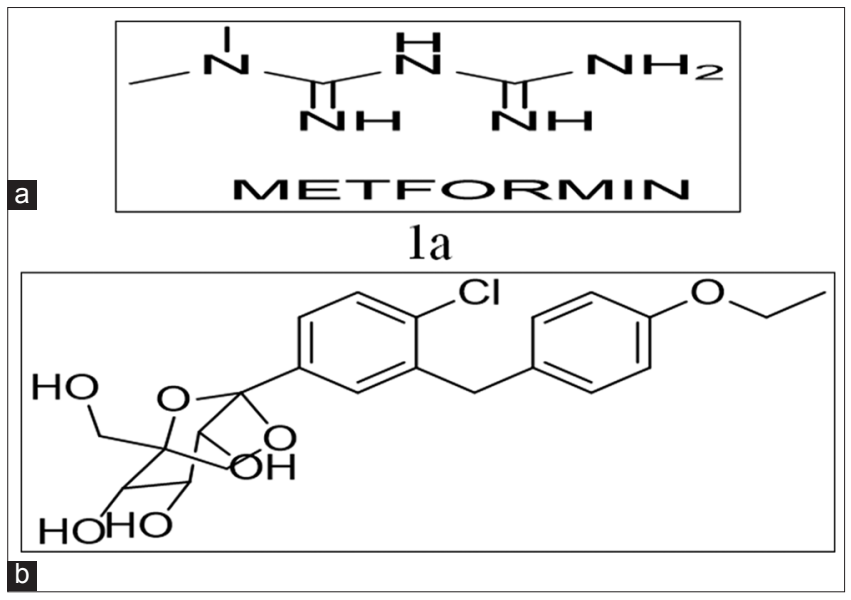

Fig. 2: Chemical structures of (a) metformin HCL, (b) ertugliflozin

\section{Chromatographic conditions}

Optimized chromatographic conditions for the separation were used as Standard BDS $\mathrm{C}_{8}(150 \mathrm{~mm} \times 4.6 \mathrm{~mm}, 5 \mu \mathrm{m}$ particle size $)$ column. Temperature was maintained ambient, mobile phase used was buffer: acetonitrile $(55: 45 \mathrm{v} / \mathrm{v})$, and the flow rate was maintained at $1 \mathrm{ml} /$ min. The diluent used throughout the method was water: acetonitrile $(50: 50 \mathrm{v} / \mathrm{v})$ and the runtime was $6 \mathrm{~min}$. All the samples and mobile phase were degassed for $30 \mathrm{~min}$ and filtered by ultrasonic filtration using 0.45 $\mu \mathrm{m}$ nylon (N66) 47-mm membrane filter. Detection was carried out at $224 \mathrm{~nm}$ using PDA detector with an injection volume of $10 \mu \mathrm{l}$. Using the above-optimized conditions, method was developed.

\section{Preparation of buffer}

Buffer: $\left(0.01 \% \mathrm{KH}_{2} \mathrm{PO}_{4}\right)$

About $1.36 \mathrm{~g}$ of potassium dihydrogen phosphate was weighed and transferred into a $1000 \mathrm{ml}$ volumetric flask added about $100 \mathrm{ml}$ of milli-Q water and finally made the volume up to $1000 \mathrm{ml}$ with milli- $\mathrm{Q}$ water.

\section{Orthophosphoric acid buffer}

$1 \mathrm{ml}$ of orthophosphoric acid was diluted to $1000 \mathrm{ml}$ with HPLC grade water.

\section{Preparation of mobile phase}

Buffer (55\%) and acetonitrile (45\%) were mixed and degassed in an ultrasonicate water bath for $10 \mathrm{~min}$ and then filtered through $0.45 \mu$ filter under vacuum filtration.

Diluent

Diluent used throughout the method was water: acetonitrile (50:50 v/v) chosen purely based on the solubility of the drugs.

\section{Preparation of standard solutions}

Accurately weighed and transferred $500 \mathrm{mg}$ of metformin hydrochloride and $7.5 \mathrm{mg}$ of ertugliflozin working standards into a $100 \mathrm{ml}$ clean dry volumetric flasks; $10 \mathrm{ml}$ of diluent was added and sonicated for $10 \mathrm{~min}$ and made up to the final volume with diluent.

\section{Preparation of sample solution}

A total of 10 tablets were weighed, and their mean weight was determined and crushed in mortar. An amount of powder weight equivalent to $500 \mathrm{mg}$ of metformin hydrochloride and $7.5 \mathrm{mg}$ of ertugliflozin was taken and transfered to $100 \mathrm{ml}$ volumetric flask. The powder obtained was dissolved in mobile phase and sonicated for 20 min for complete extraction. The solution was made up to the volume with mobile phase. The solution was filtered through membrane filter. The stock solution was further diluted with diluent to get a concentration of $500 \mu \mathrm{g} / \mathrm{ml}$ of metformin hydrochloride and $7.5 \mu \mathrm{g} / \mathrm{ml}$ of ertugliflozin.

\section{Quantitative estimation}

$\%$ Assay $\frac{\mathrm{AT}}{\mathrm{AS}} \times \frac{\mathrm{WS}}{\mathrm{DS}} \times \frac{\mathrm{DT}}{\mathrm{WT}} \times \frac{\mathrm{P}}{100} \times 100$

Where

$\mathrm{AT}=$ Average area of each main peak obtained from chromatogram of the sample solution

AS = Average area of each main peak obtained from chromatograms of the standard solution

WS = Weight of each metformin hydrochloride and ertugliflozin in standard solution $(\mathrm{mg} / \mathrm{ml})$

WT $=$ Weight of each metformin hydrochloride and ertugliflozin in sample $(\mathrm{mg} / \mathrm{ml})$

DS = Dilution of standard solution

DT =Dilution of test solution

$\mathrm{P}=$ Potency of each standard

\section{Method validation $[17,18]$}

\section{System suitability}

System suitability tests are a fundamental part of liquid chromatographic method. It ensures that system is working correctly. System suitability parameters such as number of theoretical plates, retention time, and tailing factor were evaluated. This was performed by injecting mixture of standard in six replicates.

\section{Linearity}

The linearity of the proposed method was determined by quantitative dilution of the standard solution of metformin hydrochloride and ertugliflozin to obtain a solution in concentration range of 125$750 \mu \mathrm{g} / \mathrm{ml}$ and $1.875-11.25 \mu \mathrm{g} / \mathrm{ml}$ for metformin hydrochloride and ertugliflozin, respectively. A graph of peak area versus concentration in $\mu \mathrm{g} / \mathrm{ml}$ was plotted for all three drugs in triplicate. The slope, intercept, and correlation coefficient of the regression line were determined. 
Limit of detection (LOD) and limit of quantitation (LOQ)

The LOD and LOQ represent the concentration of analyte that would yield signal-to-noise ratio of 3 for LOD and 10 for LOQ. LOD and LOQ were calculated using the following formula,

$\mathrm{LOD}=3.3 \sigma / \mathrm{S}$

$\mathrm{LOQ}=10 \sigma / \mathrm{S}$

Where $\sigma=$ standard deviation of response (peak area) and $S=$ average slope of the calibration curve.

\section{Method precision}

The method precision of the proposed method was determined by injecting six replicates of sample and standard on the same day to ensure that the analytical method is repeatable.

\section{System precision}

The system precision is checked by injecting six replicates of standard solution to ensure that the analytical system is working properly.

\section{Accuracy}

The accuracy of this method was performed at three different levels $(50 \%, 100 \%$, and $150 \%)$, by the addition of a known amount of standard to the sample at each level. Each level was repeated 3 times $(n=3)$.

\section{Robustness}

Robustness is the measure of optimized method capacity to remain unaffected by small but deliberate variations in method parameters such as mobile phase flow rate $( \pm 0.2 \mathrm{ml} / \mathrm{min})$, wavelength $\mathrm{nm}( \pm 1 \mathrm{~nm})$, and column oven temperature $\left( \pm 1^{\circ} \mathrm{C}\right)$.

\section{Degradation studies [19]}

Oxidative degradation

To $1 \mathrm{ml}$ of stock solution of metformin hydrochloride and ertugliflozin, $1 \mathrm{ml}$ of $20 \%$ hydrogen peroxide $\left(\mathrm{H}_{2} \mathrm{O}_{2}\right)$ was added separately. The solutions were kept for $30 \mathrm{~min}$. For HPLC study, the resultant solution was diluted to obtain $(500 \mu \mathrm{g} / \mathrm{ml}$ and $7.5 \mu \mathrm{g} / \mathrm{ml})$ solution and $10 \mu \mathrm{l}$ were injected into the system, and the chromatograms were recorded to assess the stability of sample.
Acid degradation

As described in the oxidative degradation, the same method was followed using $2 \mathrm{~N}$ hydrochloric acid and refluxed for $30 \mathrm{~min}$

\section{Alkali degradation}

The same procedure was followed as the above, in which $1 \mathrm{ml}$ of $2 \mathrm{~N}$ sodium hydroxide was used and refluxed for $30 \mathrm{~min}$.

\section{Thermal degradation}

The standard drug solution was placed in an oven at $105^{\circ} \mathrm{C}$ for $6 \mathrm{~h}$ to study dry heat degradation. For HPLC study, the resultant solution was diluted to $500 \mu \mathrm{g} / \mathrm{ml}$ and $7.5 \mu \mathrm{g} / \mathrm{ml}$ of solution and $10 \mu \mathrm{l}$ was injected into the system, and the chromatograms were recorded to assess the stability of the sample.

\section{Photo stability}

The photochemical stability of the drug was also studied by exposing the solution to UV light by keeping the beaker in UV Chamber for 7 days in photostability chamber. For HPLC study, the resultant solution was diluted to obtain $500 \mu \mathrm{g} / \mathrm{ml}$ and $7.5 \mu \mathrm{g} / \mathrm{ml}$ of solutions and $10 \mu \mathrm{l}$ was injected into the system, and the chromatograms were recorded to assess the stability of sample.

\section{Water degradation}

Stress testing under neutral conditions was studied by refluxing the drug in water for $6 \mathrm{~h}$ at a temperature of $60^{\circ} \mathrm{C}$. For HPLC study, the resultant solution was diluted to $500 \mu \mathrm{g} / \mathrm{ml}$ and $7.5 \mu \mathrm{g} / \mathrm{ml}$ of solution and $10 \mu \mathrm{L}$ was injected into the system, and the chromatograms were recorded to assess the stability of the sample.

\section{RESULTS}

\section{System suitability}

The system suitability was performed by injecting mixed standard solution containing $500 \mu \mathrm{g} / \mathrm{ml}$ of metformin hydrochloride and $7.5 \mu \mathrm{g} / \mathrm{ml}$ of ertugliflozin in six replicates. The acceptance criteria for evaluating system suitability are percentage relative standard deviation (\% RSD) $<2$, tailing factor $<2$, resolution $>2$, and theoretical plate $>2000$.

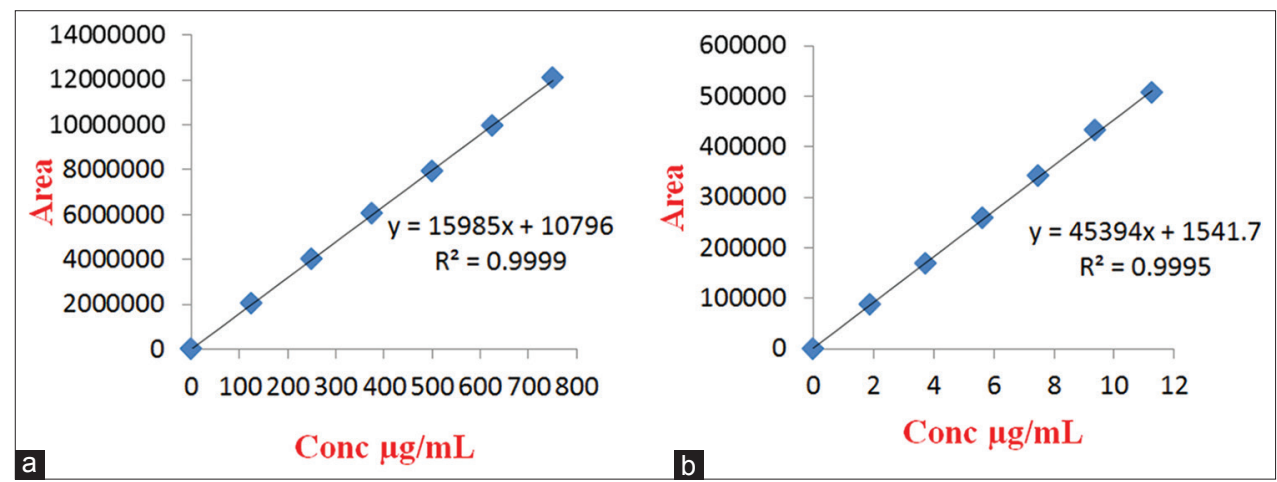

Fig. 3: Graphs representing calibration curve of (a) metformin $\mathrm{HCl}$ and (b) ertugliflozin

Table 1: Results of system suitability studies

\begin{tabular}{|c|c|c|c|c|c|c|c|}
\hline \multirow[t]{2}{*}{ Replicates $(n=6)$} & \multicolumn{3}{|c|}{ Metformin hydrochloride } & \multicolumn{3}{|c|}{ Ertugliflozin } & \multirow[t]{2}{*}{ Resolution } \\
\hline & RT (min) & USP plate count & USP tailing & RT (min) & USP plate count & USP tailing & \\
\hline 1 & 2.334 & 5356 & 1.34 & 3.136 & 7732 & 1.25 & 5.7 \\
\hline 2 & 2.335 & 5640 & 1.33 & 3.138 & 7487 & 1.25 & 5.6 \\
\hline 3 & 2.336 & 5406 & 1.32 & 3.142 & 7428 & 1.24 & 5.7 \\
\hline 4 & 2.336 & 5544 & 1.34 & 3.142 & 7225 & 1.27 & 5.7 \\
\hline 5 & 2.336 & 5241 & 1.36 & 3.142 & 6981 & 1.25 & 5.7 \\
\hline 6 & 2.338 & 5359 & 1.32 & 3.143 & 6985 & 1.26 & 5.7 \\
\hline
\end{tabular}


The result indicates that the system suitability parameters are within the acceptable limits, hence ideal for the chromatographic samples. The results are summarized in Table 1.

\section{Linearity}

Linearity of the proposed method was determined by constructing calibration graph between the tested concentration level and corresponding peak areas for metformin hydrochloride and ertugliflozin in triplicate. The results showed an excellent correlation between peak areas and concentrations level within the tested concentration range of $125-750 \mu \mathrm{g} / \mathrm{ml}$ for metformin hydrochloride and 1.875-11.25 $\mu \mathrm{g} /$ $\mathrm{ml}$ for ertugliflozin. The correlation coefficients were $>0.999$ for all two drugs, which meet the method validation acceptance criteria, and hence, the method is said to be linear for the drugs [Fig. 3a and b]

\section{LOD and LOQ}

The LOD and LOQ were found to be $1.70 \mu \mathrm{g} / \mathrm{ml}$ and $5.16 \mu \mathrm{g} / \mathrm{ml}$ for metformin hydrochloride and $0.07 \mu \mathrm{g} / \mathrm{ml}$ and $0.21 \mu \mathrm{g} / \mathrm{ml}$ for ertugliflozin which indicates that the method is sensitive. The results are summarized in Table 2.

\section{Method precision}

The \%RSD value for six replicates injection of sample and standard carried out on the same day was found to be $<2 \%$, which indicates that the method is repeatable. The results for method precision are given in Table 3.

\section{System precision}

System precision was determined by measuring the peak area of six replicate injections of standard solution. The value of \%RSD was found to be $<2$, which ensures that the analytical system is working properly. The results of system precision are tabulated in Table 3.

Table 2: LOD and LOQ results

\begin{tabular}{lll}
\hline Drug & LOD & LOQ \\
\hline Metformin $\mathrm{HCl}(\mu \mathrm{g} / \mathrm{ml})$ & 1.70 & 5.16 \\
Ertugliflozin $(\mu \mathrm{g} / \mathrm{ml})$ & 0.07 & 0.21 \\
\hline
\end{tabular}

\section{Accuracy}

The accuracy of this method was determined by calculating percent recovery of metformin hydrochloride and ertugliflozin in formulation at three different levels $(50 \%, 100 \%$, and $150 \%)$. The percentage recovery obtained was found to be in the range of $99.13-101.63 \%$ for metformin hydrochloride and $99.05-101.10 \%$ for ertugliflozin. The accepted limits of mean recovery are $98-102 \%$ and the obtained results were within the acceptable range, which indicates that recovery values were good, affirming the accuracy of the developed method. The results are summarized in Tables 4 and 5.

\section{Robustness}

The method was found to be robust when minor changes were made in optimized chromatographic conditions such as oven temperature $\left( \pm 5^{\circ} \mathrm{C}\right)$, mobile phase flow rate $( \pm 0.1 \mathrm{ml} / \mathrm{min})$, and ratio of mobile phase $( \pm 5 \mathrm{ml})$. It was observed that there was no marked change in the analytical data of the drugs which indicate good reliability during normal usage. The results are shown in Table 6.

\section{Force degradation studies}

Force degradation of metformin hydrochloride and ertugliflozin under the conditions of hydrolysis acidic, basic, oxidation, photolysis, thermal, and humidity was carried out.

In acidic conditions ( $2 \mathrm{~N}$ hydrochloride for $3 \mathrm{~h}$ ), it was found that $5.97 \%$ of metformin hydrochloride and $5.37 \%$ of ertugliflozin content were degraded, respectively.

In basic condition ( $2 \mathrm{~N}$ sodium hydroxide for $3 \mathrm{~h}$ ), it was found that $4.66 \%$ of metformin hydrochloride and $4.19 \%$ of ertugliflozin content were degraded, respectively.

The drug sample when subjected to oxidation $(20 \%$ of hydrogen peroxide), it was found that $3.64 \%$ of metformin hydrochloride and $3.86 \%$ of ertugliflozin content were degraded, respectively.

In thermal condition (at $105^{\circ} \mathrm{C}$ for $6 \mathrm{~h}$ ), it was found that $3.81 \%$ of metformin hydrochloride and $2.63 \%$ of ertugliflozin content were degraded, respectively.

Table 3: Precision data of metformin and ertugliflozin

\begin{tabular}{|c|c|c|c|c|}
\hline \multirow[t]{2}{*}{ Replicates $(n=6)$} & \multicolumn{2}{|l|}{ Intraday } & \multicolumn{2}{|l|}{ Interday } \\
\hline & Area of metformin $\mathrm{HCl}$ & Area of ertugliflozin & Area of metformin $\mathrm{HCl}$ & Area of ertugliflozin \\
\hline 1 & 8061896 & 345429 & 8083648 & 342481 \\
\hline 3 & 8054073 & 343925 & 8045907 & 340545 \\
\hline 4 & 8045184 & 343865 & 8066204 & 347348 \\
\hline 5 & 8053730 & 344007 & 8095717 & 347348 \\
\hline 6 & 8070321 & 345636 & 8022367 & 344224 \\
\hline Mean & 8063061 & 344878 & 8056603 & 344841 \\
\hline S.D & 17015.1 & 1087.4 & 30300.4 & 2900.7 \\
\hline$\%$ RSD & 0.2 & 0.3 & 0.4 & 0.8 \\
\hline
\end{tabular}

N: Number of injections, SD: Standard deviation, \% RSD: Percentage relative standard deviation

Table 4: Accuracy data for metformin hydrochloride

\begin{tabular}{lllll}
\hline \% Level & Amount spiked $(\boldsymbol{\mu g} / \mathbf{m l})$ & Amount recovered $(\boldsymbol{\mu g} / \mathbf{m l})$ & \% Recovery & Mean \%recovery \\
\hline $50 \%$ & 250 & 253.73 & 101.49 & $100.15 \%$ \\
& 250 & 254.06 & 101.63 & \\
$100 \%$ & 250 & 252.96 & 101.18 & \\
& 500 & 498.89 & 99.78 & \\
$150 \%$ & 500 & 495.99 & 99.20 & \\
& 500 & 495.67 & 99.13 & \\
& 750 & 747.76 & 99.48 & \\
& 750 & 746.09 & 99.75 & \\
\hline
\end{tabular}


Table 5: Accuracy data for ertugliflozin

\begin{tabular}{lllll}
\hline \% Level & $\begin{array}{l}\text { Amount } \\
\text { spiked } \\
(\boldsymbol{\mu g} / \mathbf{m l})\end{array}$ & $\begin{array}{l}\text { Amount } \\
\text { recovered } \\
(\boldsymbol{\mu g} / \mathbf{m l})\end{array}$ & \% Recovery & $\begin{array}{l}\text { Mean \% } \\
\text { Recovery }\end{array}$ \\
\hline $50 \%$ & 3.75 & 3.73 & 99.47 & $99.98 \%$ \\
& 3.75 & 3.72 & 99.28 & \\
$100 \%$ & 3.75 & 3.71 & 99.05 & \\
& 7.5 & 7.52 & 100.24 & \\
$150 \%$ & 7.5 & 7.56 & 100.80 & \\
& 7.5 & 7.46 & 99.42 & \\
& 11.25 & 11.22 & 99.72 & \\
& 11.25 & 11.37 & 101.10 & \\
\hline
\end{tabular}

Table 6: Robustness evaluation of method

\begin{tabular}{lll}
\hline $\begin{array}{l}\text { Change in the } \\
\text { chromatographic conditions }\end{array}$ & $\begin{array}{l}\text { \%RSD of } \\
\text { metformin HCl }\end{array}$ & $\begin{array}{l}\text { \%RSD of } \\
\text { ertugliflozin }\end{array}$ \\
\hline Flow rate (-) $0.9 \mathrm{ml} / \mathrm{min}$ & 0.3 & 0.6 \\
Flow rate (+) $1.1 \mathrm{ml} / \mathrm{min}$ & 0.1 & 0.9 \\
Mobile phase (-) 60B: $40 \mathrm{~A}$ & 0.4 & 0.9 \\
Mobile phase (+) 50B: $50 \mathrm{~A}$ & 0.5 & 0.8 \\
Temperature (-) $25^{\circ} \mathrm{C}$ & 0.6 & 0.4 \\
Temperature $(+) 35^{\circ} \mathrm{C}$ & 0.5 & 0.4 \\
\hline
\end{tabular}

RSD: Relative standard deviation

Table 7: Force degradation studies of metformin hydrochloride and ertugliflozin

\begin{tabular}{lllll}
\hline Drug & $\begin{array}{l}\text { Stress } \\
\text { conditions }\end{array}$ & Area & $\begin{array}{l}\text { \% } \\
\text { Recovered }\end{array}$ & $\begin{array}{l}\text { \% } \\
\text { Degraded }\end{array}$ \\
\hline Metformin HCl & Acid & 7618829 & 94.05 & 5.95 \\
& Alkali & 7723637 & 95.34 & 4.66 \\
& Oxidation & 7806085 & 96.36 & 3.64 \\
& Thermal & 7792853 & 96.19 & 3.81 \\
& UV & 7868537 & 97.13 & 2.87 \\
Ertugliflozin & Water & 8001805 & 98.77 & 1.23 \\
& Acid & 328541 & 94.63 & 5.37 \\
& Alkali & 332643 & 95.81 & 4.19 \\
& Oxidation & 333787 & 96.14 & 3.86 \\
& Thermal & 338068 & 97.37 & 2.63 \\
& UV & 339944 & 97.91 & 2.09 \\
& Water & 343322 & 98.89 & 1.11 \\
\hline
\end{tabular}

The drug sample when exposed to UV light for 7 days, it was found that $2.87 \%$ of metformin hydrochloride and $2.09 \%$ of ertugliflozin content were degraded, respectively.

The drug sample when placed under neutral conditions (refluxing the drug in water for $6 \mathrm{~h}$ at temperature $60^{\circ} \mathrm{C}$ ), it was found that $1.23 \%$ of metformin hydrochloride and $1.11 \%$ of ertugliflozin content were degraded, respectively.

No interference was observed due to excipients and other components that are present in the pharmaceutical dosage form and as well in the degraded products, so it can be concluded that the developed method is stability indicating reversed-phase HPLC (RP-HPLC) method for simultaneous estimation of metformin hydrochloride and ertugliflozin in the formulation combination. The results for forced degradation studies are shown in Table 7.

\section{CONCLUSIONS}

No method is available for the estimation of metformin hydrochloride and ertugliflozin combination, so a new simple, precise, accurate, and repeatable RP-HPLC method for the estimation of these simultaneously have been developed and validated according to the ICH guidelines. All the validation parameters including system suitability, linearity, accuracy, precision, LOD, LOQ and robustness were within the recommended limits of the ICH. The developed method has a total run time of 6 min, which permits the analysis of a large number of samples in a short period of time, thereby reducing solvent cost. Exposure of the drugs to different stress conditions such as acid, base, UV, thermal, photolytic, and water showed the drugs are stable in all the conditions. Developed method can be used for route analysis of these compounds simultaneously.

\section{AUTHOR'S CONTRIBUTION}

Author P. Venkateswara Rao done the literature survey, analysis of the study, and wrote the first draft of the paper. Author A. Lakshmana Rao designed the study plan, corrected the first draft of the paper, and prepared the final manuscript for submission.

\section{CONFLICTS OF INTEREST}

The authors declare that there are no conflicts of interest in the present investigation.

\section{REFERENCES}

1. Merck and Co., Inc: STEGLATRO (Ertugliflozin) Tablets, for Oral use Initial U.S. Approval. Kenilworth New Jersey: Merck and Co Inc.; 2017. p. 1-23.

2. Ertugliflozin and Metformin Hydrochloride: Drug description. Available from: http://www.rxlist.com/segluromet-drug. [Last reviewed on 2017 Dec 28]; [Last accessed on 2018 Apr 12].

3. Drug Profile for Metformin Hydrochloride. Available from: http://www. pubchem.drugbank.ca/metforminhydrochloridePubchemCID14219. [Last accessed on 2018 Apr 12].

4. Drug Profile for Ertugliflozin. Available from: https://www.drugbank. $\mathrm{ca} /$ drugs/DB11827. [Last accessed on 2018 Jan 12].

5. Drug Profile for Ertugliflozin. Available from: https://www.pubchem. ncbi.nlm.nih.gov/compound/Ertugliflozin.PubChemCID:44814423. [Last accessed on 2018 Apr 12].

6. Karimulla SK, Vasanth PM, Ramesh T, Ramesh M. Method development and validation of sitagliptin and metformin using reverse phase HPLC method in bulk and tablet dosage form. Pharm Lett 2013;5:168-74.

7. Hendy M. Improved chromatographic separation of sitagliptin phosphate and metformin hydrochloride. Int J Biomed Sci 2015;2:190-4.

8. Ashutosh S, Manidipa D, Rao NS. Development of stability indicating RP-HPLC method for simultaneous estimation of metformin hydrochloride and sitagliptin phosphate monohydrate in bulk as well as in pharmaceutical formulation. Pharm Sin 2013;4:47-61.

9. Murthy TG, Geethanjali J. Development of a validated RP-HPLC method for simultaneous estimation of metformin hydrochloride and rosuvastatin calcium in bulk and in-house formulation. J Chromatogr Tech 2015;5:252-6.

10. Arshiya S, Jagirdar S. Analytical method development and validation for the determination of sitagliptin and metformin using RP-HPLC method in bulk and tablet dosage form. J Bioanal Biomed 2014;6:120-12.

11. Inamdar HP, Ashok A. RP-HPLC method for simultaneous determination of metformin hydrochloride, rosiglitazone and sitagliptin-application to commercially available drug products. Int $\mathrm{J}$ Pharm Sci Res 2012;3:3267-76.

12. Ramesh J, Kumar NS. Stability indicating RP-HPLC method development and validation for the simultaneous determination of vildagliptin and metformin in pharmaceutical dosage form. Int J Pharm Pharm Sci 2017;9:150-7.

13. Srivani J, Umamahesh B, Veeresham C. Development and validation of stability indicating HPTLC method for simultaneous determination of linagliptin and metformin. Int J Pharm Pharm Sci 2016;8:112-5.

14. Neelima K, Prasad YR, Prasad N. Analytical method development and validation of metformin, voglibose, glimepiride in bulk and combined tablet dosage form by gradient RP-HPLC. Pharm Methods 2014;5:186-91.

15. Prasanthi $\mathrm{CH}$, Parameswari SA, Aruna G. Development and validation of RP-HPLC method for metformin hydrochloride and nateglinide in bulk and combined dosage form. Int J Pharm Pharm Sci 2016;8:267-71.

16. Rao PV, Rao AL, Prasad SV. A new stability indicating Rp-Hplc method for simultaneous estimation of ertugliflozin and sitagliptin in bulk and pharmaceutical dosage form its validation as Per ICH guidelines if there are images in this attachment, they will not be displayed. Download the 
original attachment. Indo Am J Pharm Sci 2018;5:520-9.

17. ICH. International Conference on Harmonization of Technical Requirements for Registration of Pharmaceuticals for Human Use, Validation of analytical procedure: Text and Methodology Q2 (R1); 2005.
18. ICH. Validation of Analytical Procedures: Text and Methodology. Geneva: International Conference on Harmonization, IFPMA; 1996.

19. ICH. International Conference on Harmonization of Technical Requirements for Registration of Pharmaceuticals for Human Use, Stability Testing of New Drug Substances and Products Q1B (R2); 1997. 